\title{
Ethics of Advertisement and Marketing Policies: An Indian Perspective
}

\author{
Yashmita Awasthi ${ }^{1}$, Barkha Kakkar ${ }^{2}$ \& Aakanksha Uppal ${ }^{3}$ \\ 1, 2 Assistant Professor, Institute of Technology and Science, Mohan Nagar, Ghaziabad. \\ Corresponding email: yashmitaawasthi@gmail.com \\ ${ }^{3}$ Assistant Professor, Symbiosis Centre for Management Studies, NOIDA, Constituent of \\ Symbiosis International (Deemed) University
}

\begin{abstract}
:
Marketing ethics and customer relations are at the heart of the success of every business enterprise. Customers, of course, expect the same thoughtful service. Some of the key customer standards include quality of service, responsiveness, understanding and acceptance of value-added brands. Ethical marketing is a mechanism through which the company generates consumer interest in products / management, develops strong customer image / connections and attracts all partners by integrating social and environmental concerns into products and signs of progress. India's advertising industry has expanded significantly in recent years and has become a global map. However, over the years, content, messages and methods of advertising and marketing have created serious ethical problems. In today's competitive market, companies often pursue ethical marketing practices in order to survive in a highly competitive market. The objective of this paper is to address ethical issues related to print or television advertising in India and to determine the different types of ethical advertising that are unethical in India in relation to the standards set by the Advertising Standards Council of India (ASCI). The study concluded that advertising morality was indeed a problem. Improving advertising ethics requires a strong understanding of regulations and definitions. Organizations should, therefore, determine how they actually conduct marketing that is ethically and socially responsible.
\end{abstract}

KEYWORDS: Marketing, Ethics, Advertising, Customer

\section{Introduction:}

Marketing practices have changed a lot over the past century. There has always been a missing aspect in the marketing process of sellers i.e. Customer desires come after production and sales. Focusing entirely on consumer needs was not enough because society and customers could suffer as a result of false advertising and the manufacture of harmful products. Thus the shift towards social and ethical marketing, which takes into consideration every party, namely producers, customers, society and the world, is gradually taking place (Rawat,Bhatia, Hegde, Bhat, and Tewari, 2015).

Marketing ethics is an area of applied ethics that encompasses the moral principles behind marketing and regulation. In some areas of marketing ethics (advertising ethics and promotion) media ethics overlap (Bhardwaj, 2017). Marketing ethics addresses principles and standards defining acceptable market behaviour (Reddy, 2013). It refers to the process by which companies market their goods and services to focus not only on the customer's benefit from their products, but also on the social and environmental benefits of their products. Companies focused on ethical

(C) AesthetixMS 2020. This Open Access article is published under a Creative Commons Attribution Non-Commercial 4.0 International License (http://creativecommons.org/licenses/by-nc/4.0/), which permits non-commercial re-use, distribution, and reproduction in any medium, provided the original work is properly cited. For citation use the DOI. For commercial re-use, please contact editor@rupkatha.com. 
marketing assess their decisions from a business point of view (i.e. whether the desired return is achieved through a specific marketing initiative) and from a moral point of view (i.e. whether a decision is correct or morally sound). However, the real test of how your customers react to your ads and what they believe about your business is, even though it is noble to have internal beliefs that drive their own practices.

So what is described as unethical by the marketing world? Ethics is obviously open to debate; it is not a matter of science but of philosophy, so it is not the right coherent, inherent ethical position. To put it this way, this is not a strategy; it is a philosophy. It includes everything from ensuring that advertising is honest and trustworthy through a set of shared values to building strong relationships with customers.

Advertisers sometimes take the risk of shocking the public with their ads as they seek to break through modern life's communications clutter. The average Indian today is exposed every day to a large number of advertising messages. To attract the attention of the public, advertisers may resort to questionable taste appeals and tactics. It is not surprising that over half of Indians believe that today's advertising is out of control. Social critics point to advertising as one of our consumer economy's most objectionable aspects.

Advertisements today spread at an alarmingly fast rate with internet development and the advent of social media information. With a simple post on Facebook, Twitter, Whatsapp and Instagram, a company engaged in unethical practices can be destroyed. They may lose all credibility and boycott their products by people. Any public goodwill they might have enjoyed might be lost. On the other hand, an ethical company that is honest and shows that it cares for its customers can use the same method to enjoy a rapid increase in reputation (Rawat,Bhatia, Hegde, Bhat, and Tewari, 2015).

\section{Literature Review:}

Munjal (2016) focused on studying the ethical issues that arise in print and television advertising, as well as analyzing the different types of unethical advertising in India with reference to the principles of ASCI. Using examples, the author analyzed various unethical practices used by advertisers in advertisements in India and also discussed some real-life cases solved by CCC (Consumer complaint council) following the necessary ASCI codes.

Pranav et al. (2016) investigated the intentions of consumers to consider marketers' commitment to ethical issues. A sample of urban female respondents from Malaysia, a consumer survey was performed. PLS structural equation modeling was used to analyze the data. The results showed that the aspects of product fairness and price fairness was positively correlated to the attitudes of shoppers towards the firms that resort to such practices. Additionally, shoppers' attitudes and their perceived behavioural control further influence their intentions to consider a firm's ethicality while anticipating a purchase.

Rajan (2016) studied how marketer used their dual background to recognize business opportunities. The data collected was both qualitative and quantitative data. It was found that to win customers loyalty, ethical marketing plays a key role in it by reinforcing the positive values of the brand, creating a strong citizen brand.

Rawat et al. (2015) studied the importance of ethical marketing by making the consumers aware about their rights. Data was collected through the employment of questionnaire and secondary sources of journals, books etc. A sample size of 50 people was drawn. It was found that $84 \%$ of 
the sample has been the victim of unethical marketing. More than $50 \%$ people believed that consumers were not adequately protected against such marketing. $32 \%$ of the sample shares their problems on social media sometimes. The absence of a single statutory regulatory body further exacerbates the problem. Hence it was recommended that a comprehensive law was needed to regulate advertising in all forms of media. It must provide clarity in the matter and act as a onestop booth for all matters relating to advertising. Self-regulation by the industry, and an independent regulator to regulate the misleading advertising would be very supportive. Consumers must create self-awareness and exercise their rights against fraudulent companies.

Parilti et al. (2014) investigated the factors related with ethical issues in marketing practices and to reveal possible influences of these factors on consumers' ethical decision making. It was found that consumers reflect their ethical perceptions on their purchasing behavior. Each ethical issue has been found to be a positive effect on purchasing behavior. Businesses' practices on packaging have been indicated as the most effective ethical issue on purchasing behavior. The study was considered to be a significant outcome for businesses to direct their advertising, packaging and other activities.

Caner and Banu (2014) in today's business world, managers also have to make judgments about what is ethical to do in addition to general decisions. This is not an easy task especially for marketing professionals as marketing is not only the visible interface with customers, but with all other stakeholders, it is important for marketers to take marketing ethics into account. From an individual, organizational and societal perspective, marketing ethics should be examined.

Mathenge (2013) defined that it is very difficult to identify ethical behaviour that differs from country to country in the context of integrated marketing interaction. Clear and time-oriented values of morality. However, everyone, both in business, marketing and, in particular, in advertising and marketing, must have an ethical basis for conduct in the business world and for the moral conduct of individuals.

Vassilikopoulou et al. (2008) critically discussed the opposition's and supporters' views of marketing as an unethical science through the presentation of detailed review of relevant literature. It was found that the opponents of marketing accused it for being unethical, ruining the natural environment, attacking the public with absurd advertisements and encouraging materialism in many ways. The advocates of marketing pointed out the ultimate goal of marketing as customer' satisfaction. It has been difficult to get a clear conclusion and to specify precisely whether marketing is ethical or unethical. The intense accusations are found to be the accepted belief of demarketing.

Gupta (2002) in his research on 'Advertising Ethics, ' he clarified that advertising success depends on public confidence and that there should be no use of immorality and indecency.

Rao (1987) stated that "the code of marketing ethics" would make commercials simpler, more relaxed and more user-friendly. In marketing, he stresses morality and fairness.

\section{Objective:}

The main objective of this study is to examine advertising ethics, analyze different unethical marketing practices, and understand the different principles of Advertising Standards Council of India (ASCI) and Consumer Complaints Council (CCC) decisions on unethical practices. 


\section{Ethical Values in Marketing:}

As per Rajan (2016) there are six marketing ethics that should be followed by marketers:

Honesty: Be straightforward in dealings and provide value and integrity.

Responsibility: Accept the implications of marketing practices and serve the needs of all types of customers while being good environmental stewards.

Fairness: Fairly balancing buyer and seller needs and avoiding manipulation in all forms while protecting customers ' information.

Respect: Recognize the fundamental human dignity of all the people involved through efforts to communicate, understand and meet other people's needs and appreciate others ' contributions.

Transparency: Create a spirit of openness through communication, constructive criticism, action and disclosure in marketing practices.

Citizenship: Complete all legal, economic, philanthropic and social responsibilities to all stakeholders and give back to the community and protect the environment.

\section{Common Unethical Marketing Practices:}

1. Making claims that are false, exaggerated or unchecked: Some marketers use false statements, exaggerated benefits, or make unverifiable claims about their offers in a desperate bid to compel potential and existing customers to purchase their products or services. This is common in the weight loss industry, where potential buyers are convinced by marketers that a particular product can help them shed so - and-so pounds without exercise or diet within two weeks for example Kellogg's special K Challenge.

2. Fact distortion to mislead or mislead potential buyers: This is another common marketing practice that is unethical. A typical example is when a food processing company claims that when it contains sugar or calories, its products are sugar-free or calorie-free. Such a company is only attempting to mislead potential buyers as they are unlikely to buy the products if they are made known to contain sugar or calories.

3. Obscure dark sides or side effects of goods or services: This unethical marketing practice is widespread in the natural remedies sector, where most manufacturers mislead potential buyers that their products have no side effects because they are "made from natural products." But in reality, it has been found that most of these products have side effects, especially when used for a long time. In fact, without side effects, there is no product - it is simply that the side effects may be unknown. It is better to say, "No known side effects" than to say, "No side effects do exist."

4. Stereotyping Women: Television remains among the most predominant media which, with the help of advertising, promote stereotypical gender roles. "Media has become an important source of stereotyping because it is sometimes the only source of information we have about other groups and is often a distorted view of these groups." It doesn't matter what kind of life a woman lives. Generally, the entire household product, such as soap, washing powder, etc., uses mainly women to advertise it that generates or adds to the society's stereotype about women that they are limited only within their household boundaries. The famous washing powders such as Rin, 
Tide, Fena, wheel etc. always use a woman to promote both their brand and product (Munjal, 2016).

5. Use Fear tactics: This is another common unethical salesperson marketing practice. You'll hear them say: "This price is a time-limited offer. If you don't buy now, you may have to pay a lot more to buy it later because the offer will end up in two days ' time and the price will go up." The only reason behind these statements is to prompt the potential buyer to make a spot decision. And that's incorrect.

6. Spamming: Spamming is when sending unsolicited emails to potential customers to encourage them to purchase their products or services. This is the most common unethical online marketing practice. It doesn't matter how long you send such emails. Whether you're sending them once, or sometimes, or often, you're still a spammer.

\section{Advertising Standards Council of India (ASCI) and Consumer Complaints Council (CCC):}

ASCI: Founded in 1985, it is committed to the cause of self-regulation in advertising, ensuring that customers ' interests are protected. ASCI was formed with the support of all four advertisingrelated sectors-advertisers, advertising agencies, media (including broadcasters and the press) and other sectors such as PR agencies and market research firms (https://ascionline.org/index.php/ascicodes.html).

CCC: is the heart and soul of ASCI. It is the dedicated work that this group of eminent people has put in, which has given tremendous impetus to ASCI's work and advertising self - regulation.

ASCI's objectives include monitoring, administering and promoting advertising standards in India with a view to (https://ascionline.org/index.php/ascicodes.html):

- Ensure the truthfulness and honesty of advertising representations and claims and safeguards against misleading advertising.

- Ensure that advertising does not offend generally accepted public decency norms and standards.

- Protection against the indiscriminate use of advertising to promote products or services that are generally considered to be harmful to society or to individuals or that are not acceptable to society as a whole.

- Ensuring fairness in competition and the canons of generally accepted competitive behaviour by advertising.

\section{Some Case Examples of ASCI:}

In November 2017, ASCI's CCC received 243 complaints. A total of 243 cases were brought to the notice of ASCI and suo moto action was taken against 152 advertisements and the rest were complaints from direct sources. Of the 182 advertisements receiving complaints, 65 belonged to healthcare, 96 to education, 3 to personal care, 7 to the category of food and beverages and 11 to the category of other.' Gross product efficacy exaggeration was the number one reason for complaints to be upheld, followed by a violation of the Drugs and Magic Remedies Act (DMR Act) and the Drugs and Cosmetics Rules (D\&C Rules). The other reasons were failure to provide substantial facts and figures supporting claims and advertising that was misleading by ambiguity and implication (https://www.ascionline.org/download.php?f=images/pdf/asci-novccc.pdf). 
It upheld the claim against low-cost SpiceJet carrier for claiming to be the timeliest airline in the country. The advertisement's claim,' SpiceJet-India's Most Punctual Airline,' was not substantiated by any market survey data or comparative data compared to other competitor airlines or by any third-party validation or research to prove this claim.

The ad regulator also pulled up the following advertisement:

- Rajvaidya Shital Prasad \& Sons (Hempushpa): The claim of the advertisement, "Women Health Issues? Cure from the root "has not been substantiated and is misleading by exaggeration, since the advertisement does not say" help, "but indicates certain benefits. Claim, "Hempushpa-the number 1 herb and tonic of millions of women since 90 years" has not been substantiated by market share / sales data or by validation by third parties and is misleading by exaggeration. Also, the claims 'Helpful in problems such as irregularity, lack of hunger, weakness, irritability, blood cleansing, increases beauty, pain during tough days, insufficient blood, burning sensation in palms and sole, hormonal imbalance, uterine tonic, etc.' And "Made with 32 effective herbs" has been inadequately substantiated and by exaggeration are misleading. Claim, "Don't compromise with your health, have the best Hempushpa" claim is misleading because it is ambiguous and omitted to refer to the use of glass bottle packaging over plastic. The complaint concerning Raveena Tandon's endorsement has been reviewed and it has been observed that the advertiser has not provided any evidence as to whether Raveena Tandon agrees with the claims made in the general advertisement. When viewed in conjunction with these unsubstantiated claims, the actress ' visual is likely to mislead customers about the effectiveness of the product.

- Emami Ltd (HE Deodrant): Television Commercial (TVC) depicts the celebrity's vigorous day-long activities such as jogging and sports and refers to the day-long fragrance. The claim, "Ek baar lagey Din bhar chaley" was not adequately substantiated and misleading by ambiguity and exaggeration.

- Kellogg's India Pvt Ltd (Kellogg's Special K): While the advertiser declares on the product package the protein and fiber content per serving size to enable customers to make informed decisions, the TV advertisement lacks such serve-specific reference. The claim "High Protein," "High Fiber" does not qualify per serving basis-more so when only one serving of the product is likely to be consumed within a day by a consumer as the product is an "option for breakfast." The claim, "It's high in protein and fiber," is false because it doesn't apply to the product's serving size and is misleading by ambiguity in the context of a product positioned for weight management. There is no objection to the standalone claim of "high protein and fiber foods make you feel full and keep hunger pangs away." But when viewed in conjunction with "High Protein" "High Fiber," implication misleads the claim based on $100 \mathrm{gm}$ of product. While "eating breakfast regularly" was considered acceptable as a general weight management advice, the CCC did not consider the claim statement with the advertised weight management product "regular breakfast" to be adequately substantiated with the advertised weight management product. The claim, "Eating a breakfast like Kellogg's Special K to manage weight," was considered by ambiguity and implication to be misleading. The advertiser provided email correspondence details as agreed by the celebrity (Deepika Padukone) i.e. "Mere jaise, weight management karne ke liye, eat daily breakfast," "Stay healthy and eat daily breakfast." It was noted that the celebrity did not use the name of the product in its approved statements and that the advertiser is required to comply with the advertisement 
statements endorsed by the celebrity. The disclaimers did not comply with the guidelines of the ASCI.

- Abbott Healthcare Pvt Ltd: The claim of the advertisement, "Har roz Pediasure dene se bacchon ko milte hai 37 nutrients jo immunity badhane mein madadad karein our de sure growth in 90 days" was considered by ambiguity and implication to be misleading. The TVC disclaimers were unreadable and the text was white on white. In addition, the term "sure growth" was seen as an incorrect guarantee of growth since not every child in the study showed significant growth. (Since there was no statistically significant growth in the subgroup of Taiwanese children). The data presented was an abstract only referring to weight for age $\mathrm{z}$ score (and not height) and was not considered sufficient to substantiate the claim. Despite the disclaimer "creative representation of growth" as referred to in the storyboard, the claim of "Sure growth in 90 days" and its visual representation were considered to be misleading.

- J.K. Cement Ltd (J.K. Super Cement): The visual shown in the TVC of "a rider and a pillion rider on a two-wheeler without helmets" depicted violation of traffic rules and is an unsafe and dangerous practice that shows disregard for safety and encourages negligence.

- Asian Paints Ltd (Royale Atmos): The advertisement's claim, ' But the air inside your home can be 5 times more polluted than outside, "Aapke ghar ke under ki hawa bahar ki hawa ke mukable paanch guna zyada pradushit hoti hai, Isiliye Royale Atmos iski activated carbon technology reduces harmful air pollutants making it cleaner than before". The introduction of new paint that purifies air with activated carbon technology Royale Atmos and that this paint removes harsh air pollutants has been inadequately substantiated and is misleading through exaggeration.

- LG Electronics India Pvt. Ltd. (LG Linear Inverter Compressor): The claim of the advertisement regarding fruits and vegetables staying fresh for one week in LG refrigerator due to the feature "Inverter Linear" versus the non-linear inverter refrigerator was not substantiated. The claim was also misleading due to ambiguity as the results were based on internal tests and not on real-life conditions that are subject to variability due to frequent refrigerator and/or electricity fluctuations opening and closing.

\section{CONCLUSION:}

The advertising world has travelled a long way from domestic to global industry. It is a significant source of information for some, while it is a false, misleading, and obscene source for others. Advertisement industry has recently been criticized for not always being ethical in the advertisement practices (Munjal, 2016). The government and many private organizations have made an effort to prevent exploitation by saving customers and allowing ethical business practices. Indian customers are not aware of their rights, so that government takes so many initiatives, such as campaigns, seminars, etc. The level of awareness is increasing and the products and services are becoming more specific to customers. Everyone can access the real facts about products and services with the rise in internet and technology. Customers can easily traverse the product's market rate price, quantity and brand.

Today, several forces drive businesses to practice a higher level of ethics: rising customer expectations, changing employee expectations, government legislation and pressure, inclusion by investors of social criteria, and changing business procurement practices. Companies need to 
assess whether they are actually conducting marketing that is ethically and socially responsible. Marketing ethics is a complex area; improving marketing ethics will require both normative and descriptive understanding. In this important marketing area, there are many opportunities to contribute to knowledge advancement.

There is a need to consider marketing ethics from individual and organizational perspective (Caner and Banu, 2014). Personal values and moral philosophies are the key to ethical marketing decisions from the individual perspective. Honesty, fairness, accountability, and citizenship are assumed values that can guide the organization's complex marketing decisions. Organizational value, codes and training are needed to provide consistent and shared approaches to ethical decision-making from an organizational perspective.

\section{References:}

Bharwaj, R. (2013). "Ethical Issues in Marketing Practices in India", International Journal of Research in IT and Management (IJRIM) Vol. 7, Issue 6, June- 2017, pp. 7-12 ISSN(o): 2231-4334 | ISSN(p): 2349-6517. Retrieved from: http://euroasiapub.org

Caner, D. and D. Banu. (2014). An Overview and Analysis of Marketing Ethics.International Journal of Academic Research in Business and Social Sciences, November 2014, Vol. 4, No. 11 ISSN: 2222-6990

Gupta,A. (2002) "Ethical in Advertising”, Indian Journal of Marketing, vol-xxxii, no-8, August, 2002, pp-1013.

Kumar, P. et al. (2016) Ethical Marketing Practices Viewed Through Consumer Spectacles. "Market-Tržište”, 28(1); 29-45. Retrieved from: https://hrcak.srce.hr/160391

Mathenge, G.D. (2013), "Ethical Issues in Advertising and Marketing", European Journal of Business and Innovation Research, vol-1, No-4, PP-9-19, Dec, 2013.

Munjal, N. (2016). A Study on Ethical Issues in Advertising and Analyzing Different Unethical Advertisements with results of ASCI decisions: An Indian Perspective. Eco Forum. Volume 5, Issue 2 (9), 2016

Parilti, N. et al. (2014). Ethical Issues in Marketing: An Application for Understanding Ethical Decision Making. Retrieved from: http:// e-dergi.marmara.edu.tr/ maruiibfd/ article/view/ 5000106997/5000100117.

Rajan,P.S.K.(2016). Marketing Ethics, International Journal of Management and Applied Science, ISSN: 23947926 Volume-2, Issue-11, Nov.-2016

Rao, N. S.B. (1987). "The Code of Ethics in Advertising”, Indian Journal of Marketing, vol-IVII, No.-9-10, PP26-27.

Rawat, R.S. et al. (2015). The Importance of Ethical Marketing Practices, Journal of Business Management and Economics, Februray(2015),ISSN No.2347-5471,p.p.23-30.Retrieved from: http: // innovative journal.in /jbme/index.php /jbme

Reddy, S.P. (2013). Ethics and Marketing,Asia Pacific Journal of Marketing \& Management Review,ISSN 2319-2836,Vol.2(1),January(2013).Online available at indianresearchjournals.com.

Vassilikopoulou, A. et al. (2008) The Ethical and Unethical Dimensions of Marketing. "Management Review: An International Journal", 3(2); 40-6o.

\section{Websites Consulted:}

- https://ascionline.org/

- https://ascionline.org/index.php/ascicodes.html

- https://www.ascionline.org/download.php?f=images/pdf/asci-nov-ccc.pdf 